\title{
ПСИХОЛОГО-ПЕДАГОГІЧНІ ОСОБЛИВОСТІ СТАНОВЛЕННЯ ПРОФЕСІЙНОӤ САМОІДЕНТИЧНОСТІ МАЙБУТНЬОГО ПСИХОЛОГА
}

\author{
Інна Бойченко \\ науковий співробітник відділу дослідження проблем молоді \\ Державний інститут сімейної та молодіжної політики \\ 01023, Україна, м. Київ, вул. Еспланадна, 17 а \\ i_boych@ukr.net, http://orcid.org/0000-0002-2607-5612
}

\section{Анотація}

Статтю присвячено теоретико-емпіричному вивченню проблеми становлення професійної самоідентичності майбутніх психологів. Акцентується увага на необхідності врахування особливостей ii структурних складових у професійній підготовці студентів-психологів. Теоретично обгрунтовано поняття «професійна ідентичність», «професійна ідентифікація», «професійна самоідентичність» $\mathrm{i}$ «професійна самоідентифікація». Професійна ідентичність розглядається як одне 3 важливих новоутворень особистості юнацького віку. Зазначається взаємозв'язок становлення професійної ідентичності 3 процесом фахового самовизначення. Встановлюється залежність ефективної самореалізації психолога в майбутньому від сформованості його професійної самоідентичності. Доводиться, що процеси когнітивного й індивідуального розвитку психологів в сукупності створюють основу для формування їхньої професійної ідентичності у процесі оволодіння фаховими компетентностями. Розглядається професійна ідентичність як динамічна структура, що розвивається і змінюється протягом всього життя людини. Професійна ідентичність визначається такими компонентами як екзистенційні, рольові та персональні самокатегоризації, що передбачає функціональне та екзистенційне споріднення людини і професії. Виокремлюються фактори, що здійснюють вплив на становлення професійної ідентичності майбутніх психологів. Аналізуються моделі професійної самоідентичності майбутніх фахових психологів. Акцентується увага на тому, що особистість майбутнього фахівця є однією із визначальних складових моделі успішного становлення його професійної самоідентичності. Визначається рівень усвідомленості студентами-психологами вибору своєї професії в процесі становлення їх професійної самоідентичності. Визначаються показники здатності досліджуваних студентів до самоідентичності. Виокремлюються чинники, що обумовлюють ефективність професійної самоідентичності студентів. Аналізується вплив психолого-педагогічних чинників на становлення самоідентичності досліджуваних.

Ключові слова: професійна ідентичність, професійна самоідентичність, професійна ідентифікація, професійна самоідентифікація, структурні компоненти, чинники, модель, майбутній психолог.

\section{Вступ}

Сьогочасні суспільні трансформаційні процеси актуалізують необхідність переосмислення особистістю життєвих векторів, професійних виборів, ціннісних 
орієнтирів, що грунтуються на осмисленні й утвердженні власної ідентичності та перспективах самореалізації. Відповідно цього зростає теоретична й практична значущість проблем становлення професійної самоідентичності майбутніх фахівців людиноцентристських професій і психологів, зокрема. Натомість, вітчизняна школа фахової підготовки психологів переважно залишається у сфері теоретико-знаннєвої компетенції 3 незначним вкрапленням практики. Водночас, нагальним для професійної підготовки майбутніх психологів залишається питання діагностики на початкових етапах навчання профпридатності студентів, вирахування їх індивідуальних особливостей, нахилів, переконань та професійної мотивації з метою конкретизації та полегшення процесу обрання ними подальшого спеціалізаційного напрямку у професії, визначення притаманної саме для них психологічної галузі, в межах якої майбутній психолог виявить найбільшу ефективність і конкурентоспроможність, надаючи підтримку іншим. Оскільки з'ясування цих особливостей $є$ необхідною і значущою передумовою процесу підготовки фахових психологів, видається актуальним визначення специфіки розвитку професійної самоідентичності майбутнього психолога, що, за нашим переконанням, є інтегративним особистісним утворенням, адже об'єднує ряд векторів особистісного розвитку, а саме, визначення і прийняття своєї ролі у професійній групі, окреслення міри професійної спроможності й компетентності, спроможність до побудови перспективного плану фахової самореалізації тощо.

Пошуки специфіки професійної підготовки, професіоналізму, психологічної та професійної готовності майбутнього психолога здійснювались у межах таких наукових підходів, як особистісно-орієнтований (І. Бех, І. Булах, К. Роджерс, В. Франкл, Е. Фромм, I. Якиманська та ін.), ціннісно-смисловий (I. Бех, А. Деркач, О. Сапогова, Л. Баєва, Є. Клімов та ін.) та особистісно-діяльнісний (О. Леонтьєв, Б. Ананьєв, О. Бондаревська, А. Деркач, М. Д'яченко, Л. Кандибович, В. Серіков та ін.). А вивчення проблеми становлення професійної самоідентичності майбутніх психологів у ході їх навчальнопрофесійної підготовки, а саме її компонентів, рівнів розвитку і чинників впливу на іï становлення не здійснювалося раніше у межах особистісно-професійного підходу.

Мета дослідження - визначення особливостей становлення професійної самоідентичності майбутніх психологів. Завдання дослідження: 1) визначити теоретичні підходи до проблеми професійної ідентичності та самоідентичності в умовах фахової підготовки; 2) дослідити психолого-педагогічні особливості процесу становлення самоідентичності в ході навчально-професійної діяльності.

\section{Методи дослідження}

Для виявлення особливостей становлення професійної самоідентичності майбутніх психологів у дослідженні застосовувалися ряд методик: 1) «Методика дослідження самооцінки особистості» (авт. С. Будассі); 2) Методика «Самооцінка психічного стану: самопочуття, загальна активність, настрій (САН)» (авт.: В. Доскін, Н. Лаврентьєва, В. Шарай, М. Мірошников); 3) «Шкала реактивної та особистісної тривожності» (розроблена Ч. Спілбергером, адаптована Ю. Ханіним); 4) анкета «Професійний вибір та навчально-професійна адаптація майбутніх психологів» (авт. І. Бойченко); 5) «Методика вивчення професійної ідентичності (МВПІ) (авт. Л. Шнейдер). 


\section{Результати та дискусії}

Дослідження проблем самоідентичності тісно пов'язані з процесом професійного становлення особистості майбутнього психолога. Так, на розробку теоретичних i методологічних засад професійної підготовки, на вивчення проблем розвитку професійної самоідентичності спрямовані дослідження: професійної ідентичності як складової самосвідомості особистості (I. Дружиніна, В. Осьодло), компонентів професійної ідентичності (С. Каліщук, В. Кириченка), рівнів розвитку професійної ідентичності та ії функцій (В. Зливкова, В. Овсянникова та ін.), що здійснювались у межах особистіснопрофесійного підходу.

У межах вище означених досліджень вченими підкреслювалася необхідність вивчення ідентичності в різноманітті проявів та єдності всіх іiі сторін, з урахуванням інтенціональної сутності, а також в контексті інтерактивних, перцептивних, комунікативних, екзистенціальних, функціональних, ментальних i мовних процесів психічного розвитку (О. Бондаренко, Ж. Вірна, О. Леонтьєв, С. Максименко).

Спільним у визначенні понять «професійна ідентичність» $\mathrm{i}$ «професійна ідентифікація» у різних науках (філософія, соціологія, психологія) є підхід за яким тотожність і ототожнення особистості розглядається через суспільну взаємодію, одним 3 елементів якої є іï професійна діяльність (Юм, 2001). Ця взаємодія відбувається за допомогою процесів ідентифікації та самоідентифікації, як самостійного ототожнення особистості з певними фахівцями, з окремими професійними групами, що в конкретноісторичній ситуації виступають для них найбільш пріоритетними при збереженні уявлень про цілісність і унікальність індивідуального «Я» (Стояно, 2004).

Аналіз поняття «професійна ідентичність», представлений в працях багатьох авторів (Barbour \& Lammers, 2015), (Neary, 2014), (Pratt, Rockmann, \& Kaufmann, 2006), вказує на те, що загальноприйнятого визначення цього феномену не існує.

В загальному у психології поняття «професійна ідентичність» визначається як властивість психіки людини в концентрованому вигляді виражати для неї те, як вона уявляє собі свою приналежність до професійної групи чи спільноти чи ототожнення себе 3 тією чи іншою людиною, як втіленням притаманних цій групі чи спільноті властивостей. Професійна ідентифікація, з психологічної точки зору, є необхідною умовою професійної самосвідомості особистості. Вона передбачає прийняття провідних професійних ролей, цінностей та норм, котрі спонукають особистість до ефективної практичної діяльності (Панок, 1999). У свою чергу, професійна самоідентичність особистості, визначається психологами через сформовані навчально-професійні інтереси, цілі, очікування, дії, досягнення, результати, якості, що складають потенціал професіонала, цінностей його майбутньої професійної діяльності тощо (Варбан, 1998). За К. Тенопір (Tenopir, 2009) та Й. Хансоном (Hansson, 2010) професійна ідентичність особистості у процесі іiі роботи вибудовується у напрямку від дослідження своєї професії до професійного впливу на інших. А професійна самоідентифікація у ході засвоєння певної системи знань, норм, цінностей, оволодіння професійними уміннями забезпечує особистісне становлення майбутнього фахівця. Цінності майбутньої професійної діяльності набуваються у процесі формування професійних інтересів, цілей, очікувань, дій, досягнень, якостей.

За А. Ватерманом (Waterman, 1982), вибір професії та професійного шляху $\epsilon$ одними 3 найбільш значимих сфер життя для становлення самоідентичності. Для 
юнацького віку самоідентифікація у різних сферах життя, зокрема в професійній діяльності, є одним 3 важливих особистісних новоутворень. За Е. Еріксоном, метою формування ідентичності у цей віковий період $\epsilon$ усвідомлення певної життєвої продуктивності (Еріксон, 1996).

У процесі професіогенезу професійна ідентичність забезпечує цілісність особистості та задоволення потреб суспільного розвитку у тріаді «особистість-діяльністьсоціум» (Кудрявцев, 1981), (Бодров, 1991), (Цільмак, 2013).

Дослідження присвячені вивченню самоідентичності особистості в процесі професійної підготовки (Adamek, 1971) показали, що особистісна самоідентичність у професійному навчанні в ряді випадків відбувається стихійно, має не завжди передбачувані наслідки і може призводити до непередбачуваних негативних наслідків, навіть до неадекватної самоідентичності майбутнього спеціаліста в професійному навчанні.

Проблеми формування професійної самоідентичності в повному обсязі актуальні в процесі підготовки майбутніх психологів. Дослідження показують недостатньо ефективний процес самоідентифікації майбутніх психологів. Це виражається в тому, що майбутні спеціалісти недостатньо ідентифікують себе з професійним ідеалом (Джемс, 1982), не повністю усвідомлюють свою належність до психологічної професії і їм важко визначити, в чому полягає їх особистісно-професійна індивідуальність (Ely, 1997).

Таким чином, виходячи 3 досліджень вітчизняних i зарубіжних вчених можна стверджувати, що професійна самоідентичність, як частина ідентичності особистісної, постає системним, динамічним, рівневим явищем, що характеризує прийняття особистістю професійних ціннісних позицій. Професійна самоідентичність $є$ активним особистісним проявом усвідомленого ставлення до обраної професії, позаяк оцінювання професійної самоідентичності відбувається на основі суб'єктивних показників, включаючи професійну самооцінку, професійне самовизначення, задоволеність працею, професією, кар'єрою, собою тощо (Поваренков, 1991).

3 огляду на вище зазначене та спираючись на попередньо окреслені позиції науковців ми визначаємо професійну самоідентичність майбутнього психолога як сформований адекватний «Я-образ» особистості у межах специфіки професії. Цей «Яобраз» включає особистісні уявлення про професію, своїх вчителів і професійних прототипів, знання і використання професійної лексики, послуговування професійними цінностями та моральними нормами, прийнятий еталон професійної діяльності (переконання). При цьому «образ професії» виступає через прийняття професійних цінностей, визначені професійні цілі, очікування, дії, досягнення, результати, якості, що складають фаховий потенціал з емоційно-позитивним супроводом прийняття себе в якості суб’єкта професійної діяльності, що викликає задоволеність від обраної професії.

Таким чином, розвинені структури професійної ідентичності, на основі яких можна говорити про професійну самоідентичність, дозволяють адаптуватися у професійному середовищі й успішно виконувати практичні професійні обов'язки фахового психолога.

При аналізі доцільності формування професійних структур самоідентичності логічно постає питання виокремлення тих факторів, що тією чи іншою мірою здійснюють вплив на становлення професійної ідентичності майбутніх психологів. Так, розвиток професійної ідентичності залежить від емоційно-позитивного сприйняття себе як 
майбутнього професіонала (фактично в якості суб'єкта професійної діяльності), позитивного ставлення до отриманої інформації про майбутню професію, від якого залежить формування образу професії (Овсянникова, 1981) та успішного засвоєння прав й обов'язків, норм і цінностей професійної діяльності для ефективної професійної діяльності в майбутньому.

Важливою умовою ефективності процесу становлення професійної ідентичності особистості безперечно є особистісні уявлення про необхідний комплекс професійних знань, професійно-значущі якості, навички, уміння та відповідні цінності, самооцінку, а також усвідомлення означеною особистістю сутності своєї майбутньої професії, своїх професійних можливостей, емоційно-позитивного ставлення до неї, необхідності прагнення до самовдосконалення в своїй майбутній діяльності, усвідомлення і виокремлення професійно-значущих якостей своєї професії, що, у свою чергу, $\epsilon$ характерним для самоідентичності.

Виходячи 3 цього, на першому етапі дослідження особливостей становлення самоідентичності майбутніх психологів нами було поставлено завдання на виявлення рівня усвідомленості студентами-психологами III-V-x курсів вибору своєї професії в процесі становлення їх професійної самоідентичності в ході навчально-професійної діяльності. 3 цією метою було використано розроблену нами анкету «Професійний вибір та навчально-професійна адаптація майбутніх психологів» (авт. І. Бойченко) та проведено «Методику вивчення професійної ідентичності (МВПІ) Л. Шнейдер» (Шнейдер, 2004). Студентам-психологам були запропоновані слова-реакції, що потрібно було обрати для самоопису себе в категоріях професійного та непрофесійного.

Результати обстеження дали такі показники здатності до самоідентичності студентів-психологів III-V курсів.

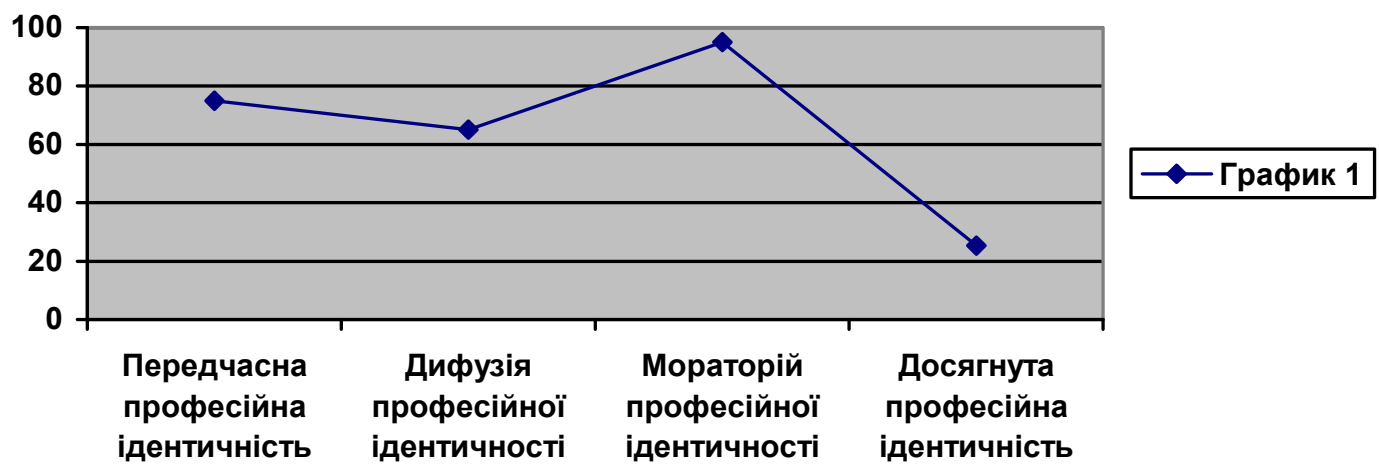

\section{Рис.1. Рівень усвідомленості вибору професії студентами-психологами}

3 них 95,01\% досліджуваних студентів-психологів перебували у стані мораторію професійної ідентичності, 75,03\% - у стані передчасної професійної ідентичності, 65,02\% - мали стан дифузії професійної ідентичності, у 25,33\% - спостерігався стан досягнутої, усвідомленої, позитивної професійної ідентичності.

Досліджувані студенти-психологи, які знаходяться у стані мораторію професійної ідентичності, зустрічаються 3 труднощами під час навчання в інституті. Тобто, ефективному становленню їхньої професійної самоідентичності заважають розрив між 
викладанням і можливістю застосування знань на практиці, а також напруження від великого обсягу літератури для читання.

Аналіз обраних слів-реакцій студентами-психологами характерних для стану передчасної професійної ідентичності виявив наступні особливості усвідомлення ними необхідності становлення їхньої професійної ідентичності. Так, у досліджуваних студентів мотивами вибору їхньої майбутньої професії $є$ такі, як бажання допомагати людям у вирішенні їхніх проблем, пізнавати себе та оточуючих, спілкуватися 3 людьми та, щоб розібратися в собі. Також їхній вибір професії $\epsilon$ зазвичай завчасно продуманий, усвідомлений ними самими чи неусвідомлений, коли професія була обрана їхніми батьками, ріднею. Ці студенти вивчають усі обов'язкові вузівські дисципліни, незалежно від особистого інтересу до них; відвідують додаткові заняття, факультативи, курси, тренінги, щоб розширити свої професійні знання та перспективи; бажають працювати в якості психолога. Вони можуть робити спроби працювати за спеціальністю (психологом у школі, в соціальній роботі), мають чіткі уявлення про своє майбутнє місце роботи.

Для ефективної професійної діяльності майбутнім психологам, які знаходяться у стані дифузії, потрібні знання з таких галузей психології: «психоконсультування та психокорекція», «політична психологія», «психологія спілкування», «соціальна психологія», «вікова психологія», «психодіагностика», «профілактика та корекція відхилень у поведінці».

Студенти-психологи, які за результатами дослідження знаходяться у стані досягнутої, усвідомленої, позитивної професійної ідентичності вибірково ставляться до навчання, оволодівають тим, що вважають особливо важливим; налагоджують контакти 3 фахівцями обраної галузі, цікавляться щодо попиту на спеціалістів останньої. Вони бажають продовжити навчання в практично-орієнтованих психологічних навчальних закладах, приймати участь у тренінгах, займатися самоосвітою (читати додаткову літературу, відвідувати додаткові навчальні заняття, факультативи, курси), щоб розширити свої професійні знання та перспективи. Роблять спроби власної практичної діяльності у таких сферах практики як шкільний психолог, психолог в соціальній роботі, співробітник науково-дослідного інституту, дошкільний психолог, терапевтична практика. Такі студенти отримують допомогу спеціалістів-наставників з психології під час їхньої психологічної практики. Результатами цієї практики є отримані професійні знання, вміння та навички через застосовування ними знань, набутих під час навчання, підвищення рівня свого професіоналізму.

Із аналізу проведених методик, ми з'ясували, що переважаючими типами усвідомленості студентами-психологами свого професійного вибору в ході навчальнопрофесійної діяльності $є$ мораторій професійної ідентичності, передчасна професійна ідентичність та дифузія професійної ідентичності. Було 3'ясовано, що переважна більшість майбутніх психологів зустрічається з труднощами під час навчання в інституті, що проявляються у складності застосування теоретичних знань на практиці та у неготовності до засвоєння великого обсягу навчального матеріалу. В процесі становлення професійної ідентичності особистості однією з характерних особливостей, а у нашому випадку, однією з визначальних причин перебування переважної більшості досліджуваних студентів у психологічних станах мораторію і дифузії професійної ідентичності може бути неусвідомлений або недостатньо усвідомлений вибір професії останніми. 
За даними анкетного дослідження «Професійний вибір та навчально-професійна адаптація майбутніх психологів» (авт. І. Бойченко) було виокремлено 32\% досліджуваних студентів-психологів, зорієнтованих на практику та $68 \%$ досліджуваних студентівпсихологів, зорієнтованих на теорію. Досліджувані психологи-практики також мають наставників-спеціалістів з психології у своїх спробах практичної діяльності.

Для вирішення другого завдання першого етапу дослідження на виявлення психолого-педагогічних чинників, що обумовлюють ефективність професійної самоідентичності студентів-психологів, ми використали ряд методик: 1) «Методика дослідження самооцінки особистості» (авт. С. Будассі) (Будасси, 1972); 2) Методика «Самооцінка психічного стану: самопочуття, загальна активність, настрій (САН)» (авт.: В. Доскін, Н.Лаврентьєва, В. Шарай, М. Мірошников) (Рогов, 1999); 3) «Шкала реактивної та особистісної тривожності» (розроблена Ч. Спілбергером, адаптована Ю. Ханіним) (Рогов, 1999).

Результати дослідження показали, що неадекватно завищена самооцінка спостерігалася у 75,03\% досліджуваних студентів - психологів, які зорієнтовані на практику під керівництвом наставників в процесі навчання. Високий рівень самооцінки складає 25,33\% досліджуваних студентів. У нашому дослідженні неадекватно завищений рівень самооцінки майбутніх психологів, які зорієнтовані на практику під керівництвом наставників, говорить про деформацію їхньої особистості, не сформованість належних вимог до себе, що може викликати стан фрустрації у випадку вибору цією особистістю складних для неї цілей. Причиною цього може бути недостатній рівень їхньої навчальнопрофесійної підготовки i, відповідно, неповне розуміння вимог до майбутньої практичної діяльності.

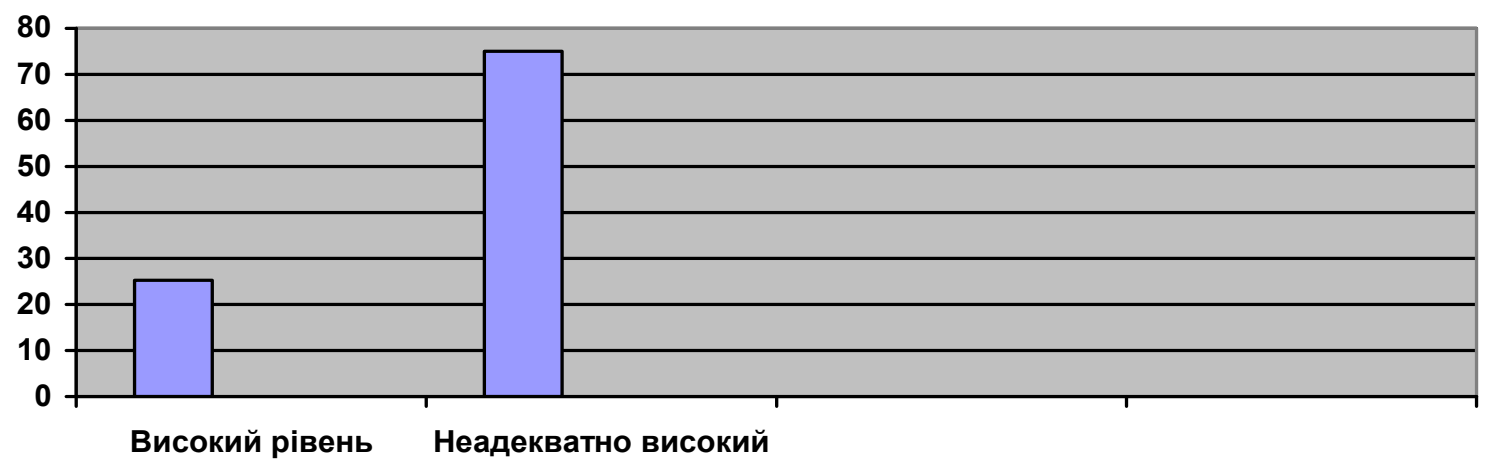

\section{Рис. 2. Рівень самооцінки студентів-психологів, які зорієнтовані на практику під керівництвом наставників в ході навчання}

$52,31 \%$ досліджуваних студентів-психологів, які зорієнтовані на теоретичну діяльність без керівництва наставників під час навчання мали високий рівень їхньої самооцінки, а однакова кількість - по 24,08\% - мали низький та середній рівень їхньої самооцінки. Так, результати високої самооцінки, що отримала більша половина досліджуваних студентів свідчить про достатньо високий рівень проби себе у теоретичній сфері під час професійного становлення. I навіть за відсутності мотиваційної зорієнтованості на їхню практику наставниками (спеціалістами-психологами), такі студенти є успішними у теоретичній діяльності з набуття фаху. 


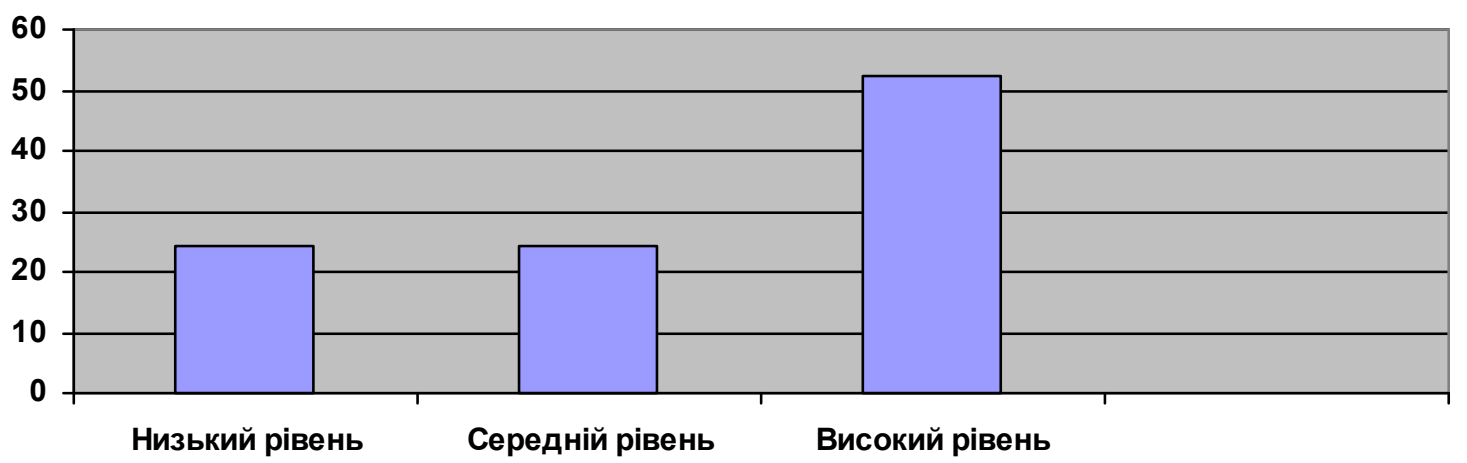

\section{Рис. 3. Рівень самооцінки студентів-психологів, які зоріснтовані на теорію без керівництва наставників під час навчання}

За результатами опитувальника «САН» було з'ясовано, що сприятливий стан функціональної активності спостерігався у 85,03\% досліджуваних студентів-психологів, зорієнтованих на практику під керівництвом наставників в ході навчання, а 15,23\% - в нормі. Той факт, що переважна більшість досліджуваних студентів, які зорієнтовані на практику під керівництвом наставників знаходиться в сприятливому функціональному стані для ефективної роботи в ході навчального процесу пояснюється тим, що професійна підтримка цих студентів наставниками (спеціалістами-психологами) є ефективною.

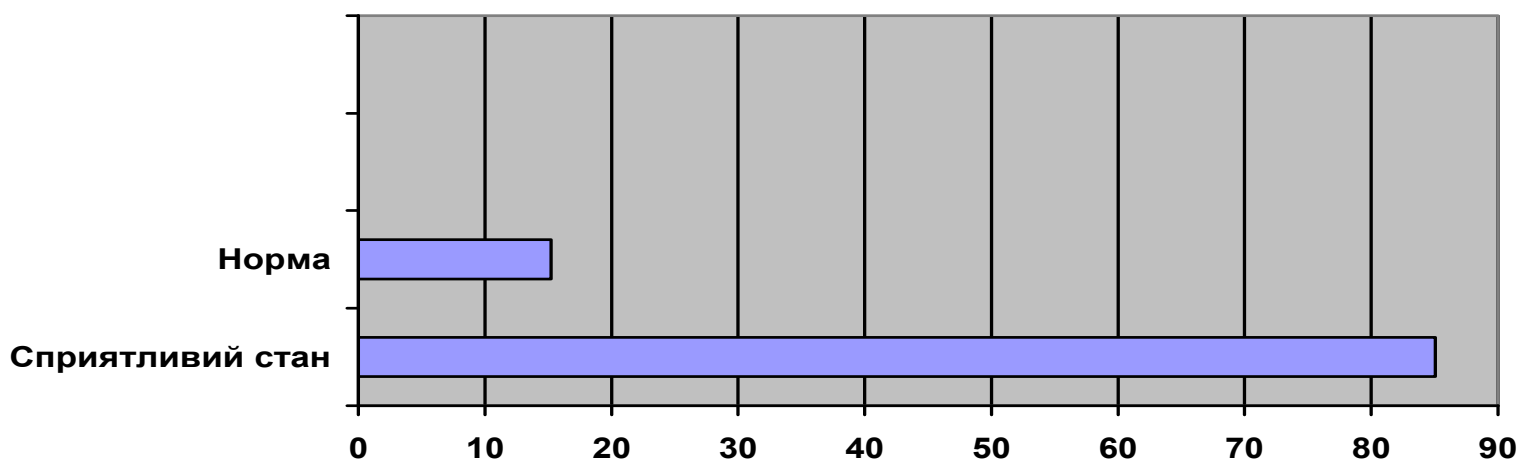

Рис. 4. Рівні загального функціонального стану активності студентів-психологів, які зоріснтовані на практику під керівництвом наставників в ході навчання

За результатами дослідження функціонального стану активності студентівпсихологів, які зорієнтовані на теорію без керівництва наставників під час навчання було 3'ясовано, що 84,33\% студентів знаходяться у сприятливому стані, а 15,01\% - в нормі. Це свідчить, що під час навчально-професійної діяльності студенти-теоретики почувають себе комфортно під час навчання, мають сприятливий стан для досягнення ефективних результатів в ньому. 


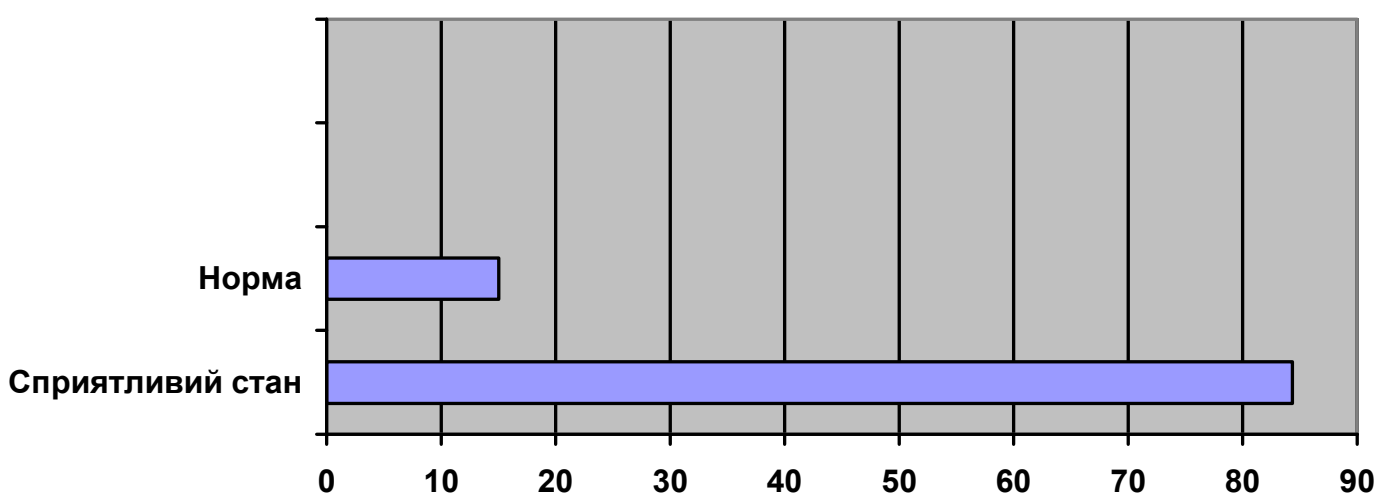

Рис. 5. Рівні загального функціонального стану активності студентів-психологів, які зорієнтовані на теоретичну діяльність без керівництва наставників під час навчання

У 75,02\% досліджуваних студентів-психологів зорієнтованих на практику під керівництвом наставників у ході навчання спостерігався середній рівень пізнавальної активності, а у $24,08 \%$ - високий рівень.

У цих досліджуваних студентів виникають бажання 3 великою зацікавленістю дізнатися, що вивчають під час навчальних занять. Також досліджувані майбутні психологи відчувають себе дослідниками у спробах освоїти професію.

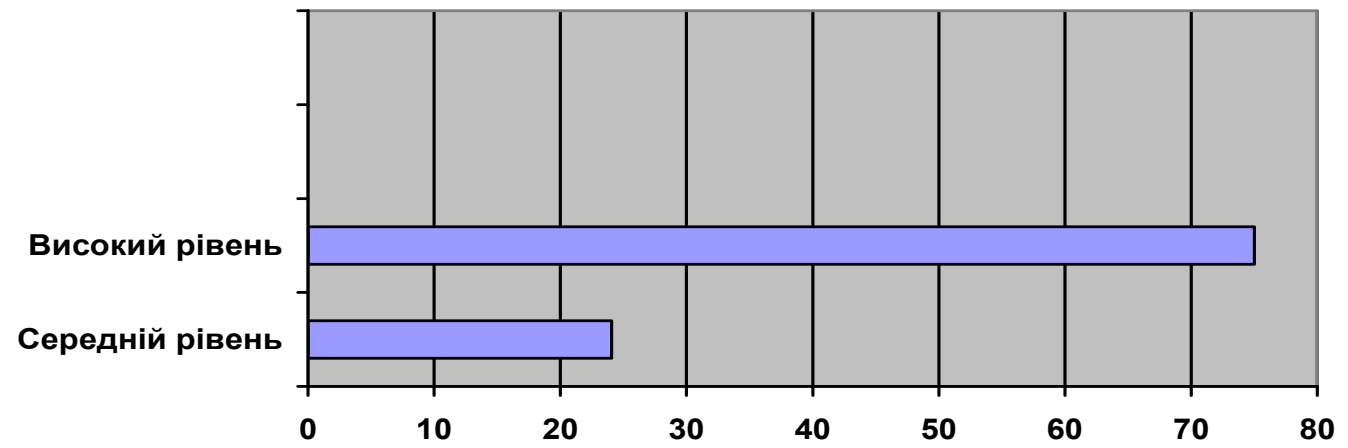

Рис. 6. Рівні пізнавальної активності студентів-психологів, які зоріснтовані на практику під керівництвом наставників в ході навчання

Результати дослідження рівня пізнавальної активності студентів-психологів, які зорієнтовані на теоретичну діяльність без керівництва наставників під час навчання показали, що у 84,22\% студентів спостерігається середній рівень пізнавальної активності, а у 14,09\% - високий рівень. Це говорить про те, що ці студенти достатньо зорієнтовані на навчально-професійну діяльність. Їм подобаються ті навчальні предмети, які вони вивчають. 


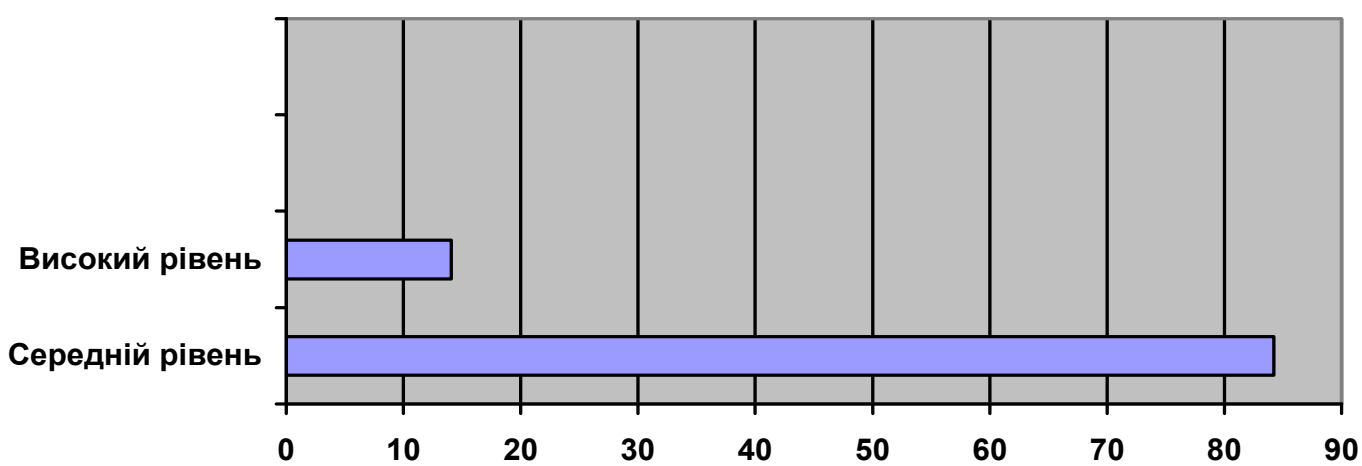

Рис. 7. Рівні пізнавальної активності студентів-психологів, які зоріснтовані на теорію без керівництва наставників під час навчання

За результатами опитування на виявлення рівня тривожності студентів, зорієнтованих на практику під керівництвом наставників в ході навчання було з'ясовано, що 85\% опитуваних мають середній рівень тривожності, а 15\% - низький рівень. Це говорить про те, що ці студенти ще не впевненні у своїх професійних знаннях, уявленнях, вміннях, навичках. Мають недостатньо сформований образ професії та рівень володіння професійно-значущими якостями.

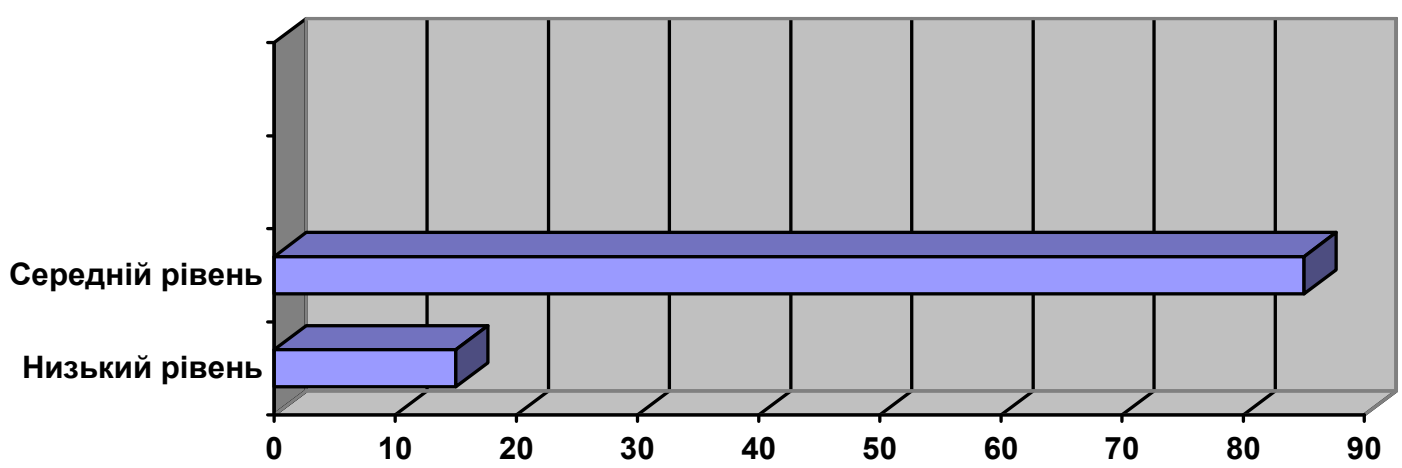

Рис. 8. Рівні тривожності студентів-психологів, які зоріснтовані на практику під керівництвом наставників у ході навчання

Результати опитування з метою виявлення рівня тривожності студентів-психологів, які зорієнтовані на теорію без керівництва наставників під час навчання показали, що середній рівень тривожності мали 65,03\% досліджуваних, а 34,07\% - низький рівень. Це говорить про те, що майбутні психологи-теоретики теж відчувають тривогу під час навчання, як і майбутні психологи-практики. Цей стан тривожності майбутніх психологів можна пояснити невпевненістю в собі, у своїх можливостях в процесі оволодіння ними професійними знаннями, уміннями під час навчально-професійного процесу, а також відсутністю професійної підтримки з боку наставників-фахівців. 


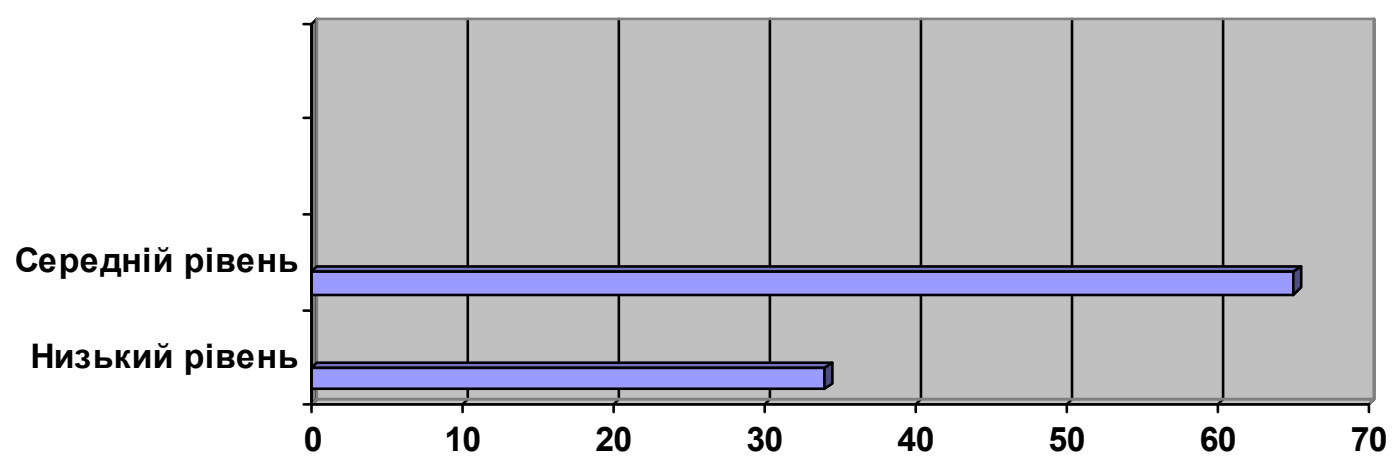

\section{Рис. 9. Рівні тривожності студентів-психологів, які зоріснтовані на теорію без керівництва наставників під час навчання}

Результати опитування 3 метою визначення рівнів нервово-емоційного переживання студентів-психологів, які зорієнтовані на практику під керівництвом наставників в ході навчання показали, що 74,09\% досліджуваних майбутніх психологів мають низький рівень нервово-емоційного переживання, 25,01\% - середній рівень. Це говорить про те, що студенти-психологи вже в деякій мірі адаптувалися до навчальної діяльності. Їх вже менше напружують вивчення великого об'єму навчальної інформації і те, як вони будуть їі відтворювати, а також практичні спроби у їхній майбутній професійній діяльності. Це може бути одним із результатів професійного впливу наставників на формування емоційно-позитивного ставлення студентів до їхньої майбутньої професійної діяльності.

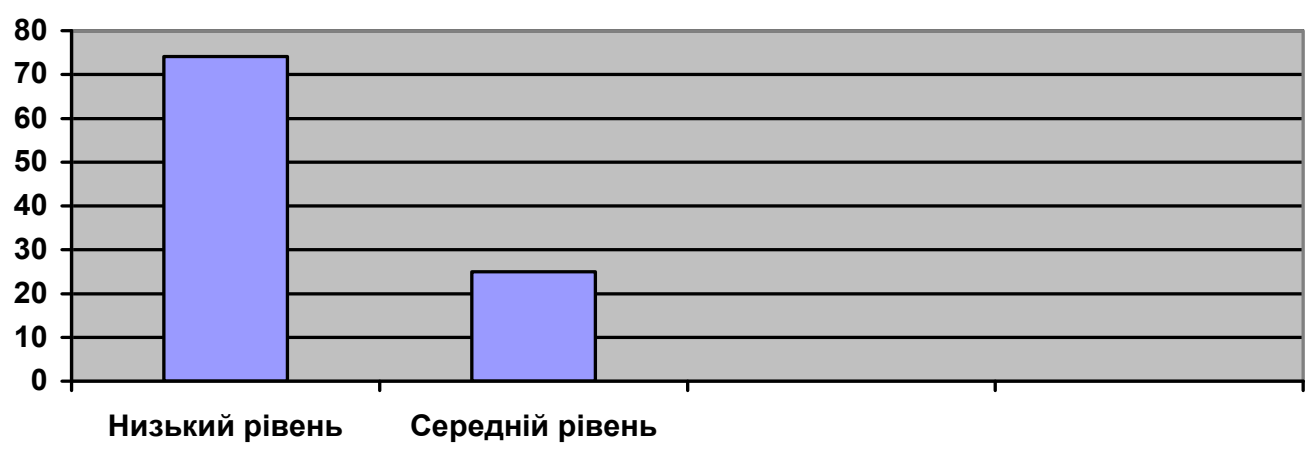

Рис. 10. Рівні негативно-емоційного переживання студентів-психологів, які зорієнтовані на практику під керівництвом наставників в ході навчання

Отримані результати дослідження стану нервово-емоційного переживання майбутніх психологів, які зорієнтовані на теорію без керівництва наставників показали, що 75,03\% студентів мають середній рівень нервово-емоційного переживання, а 24,06\% низький рівень. Це означає, що ці студенти відчувають нервове напруження під час навчання. Вони ще не адаптувалися до навчального процесу. Відчувають невпевненість у своїх знаннях, уміннях, тому що не мають достатньої професійної практики. 


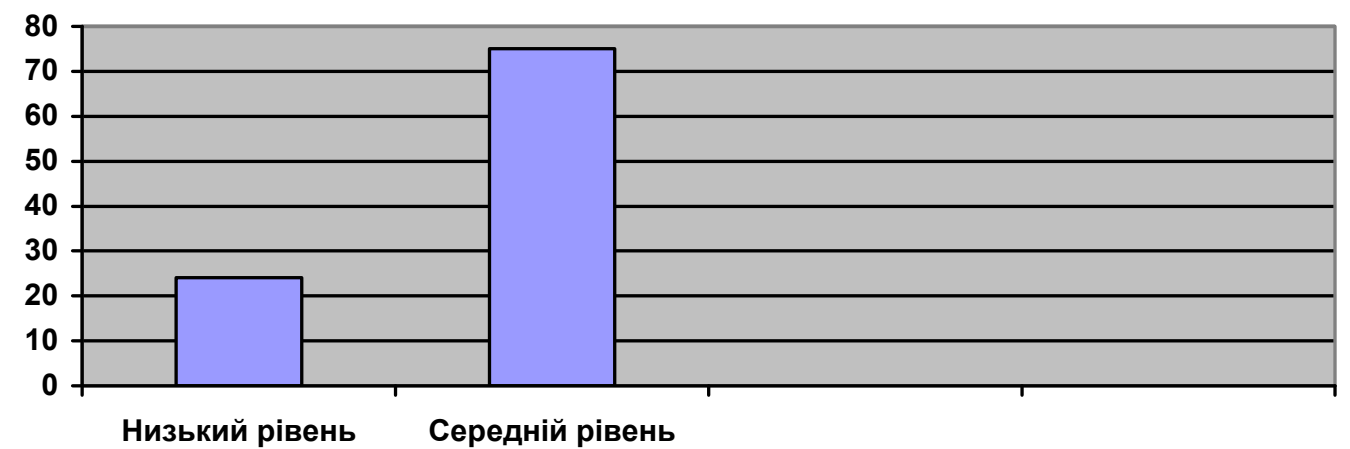

Рис. 11. Рівні негативно-емоційного переживання студентів-психологів, які зоріснтовані на теорію без керівництва наставників під час навчання

За результатами опитування студентів-психологів, які зорієнтовані на практику під керівництвом наставників з метою виявлення їхнього рівня пізнавальної активності у звичайному стані було з'ясовано, що 64,01\% опитуваних студентів мала низький рівень досліджуваної активності за умов перебування поза навчанням, а 35,09\% - середній рівень. Це вказує на те, що студенти-психологи, які зорієнтовані на практику, у звичайному стані не проявляють вираженої загальної пізнавальної активності.

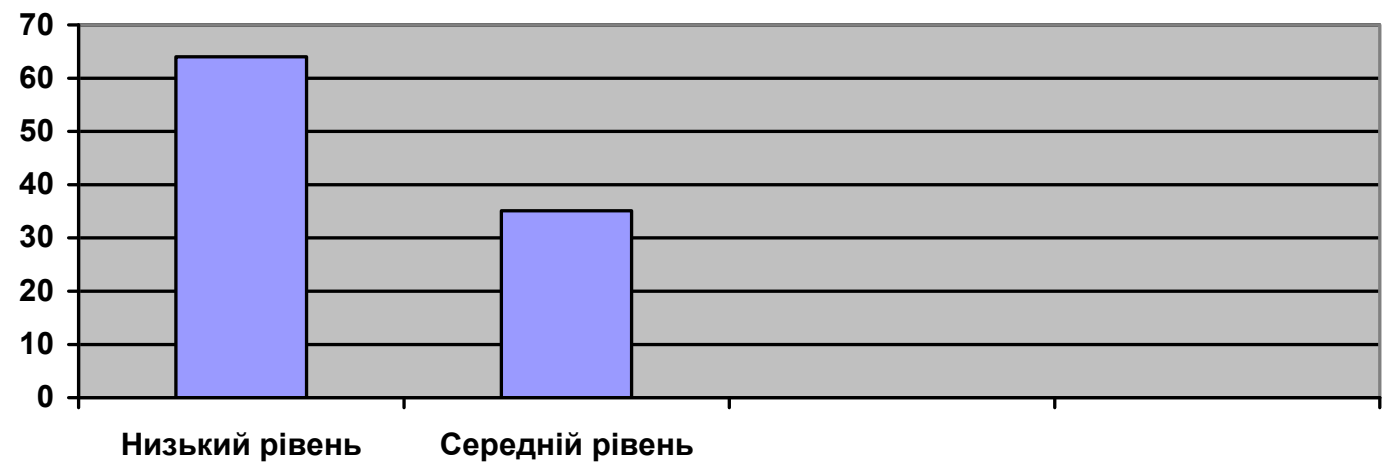

Рис. 12. Рівні пізнавальної активності студентів-психологів, які зоріснтовані на практику під керівництвом наставників, у звичайному стані

За результатами опитування студентів-психологів, які зорієнтовані на практику під керівництвом наставників на виявлення їхнього рівня тривожності у звичайному стані було констатовано, що 85,01\% досліджуваних студентів мають високий рівень загальної тривожності за умов перебування поза навчанням, а 14,07\% - середній рівень. 


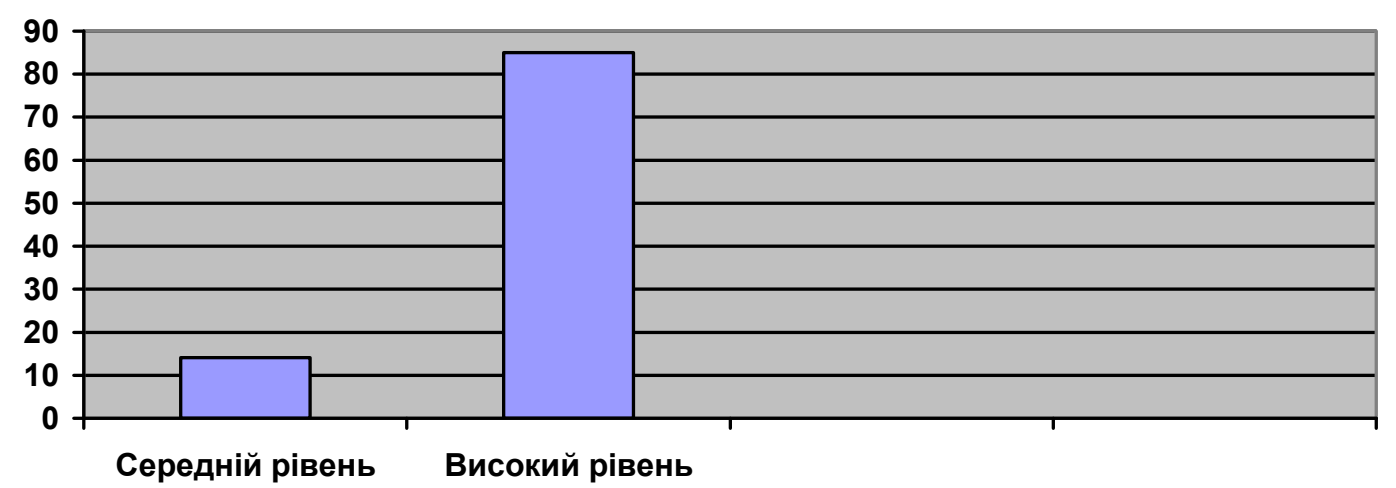

\section{Рис. 13. Рівні тривожності студентів-психологів, які зоріснтовані на практику під керівництвом наставників, у звичайному стані}

Результати опитування студентів-психологів, які зорієнтовані на практику під керівництвом наставників 3 метою з'ясування їхнього рівня нервово-емоційного переживання у звичайному стані, вказують на те, що 77,33\% студентів мають середній рівень нервово-емоційного переживання за умов перебування поза навчанням, а 11,01\% високий, 12,05\% - низький рівні.

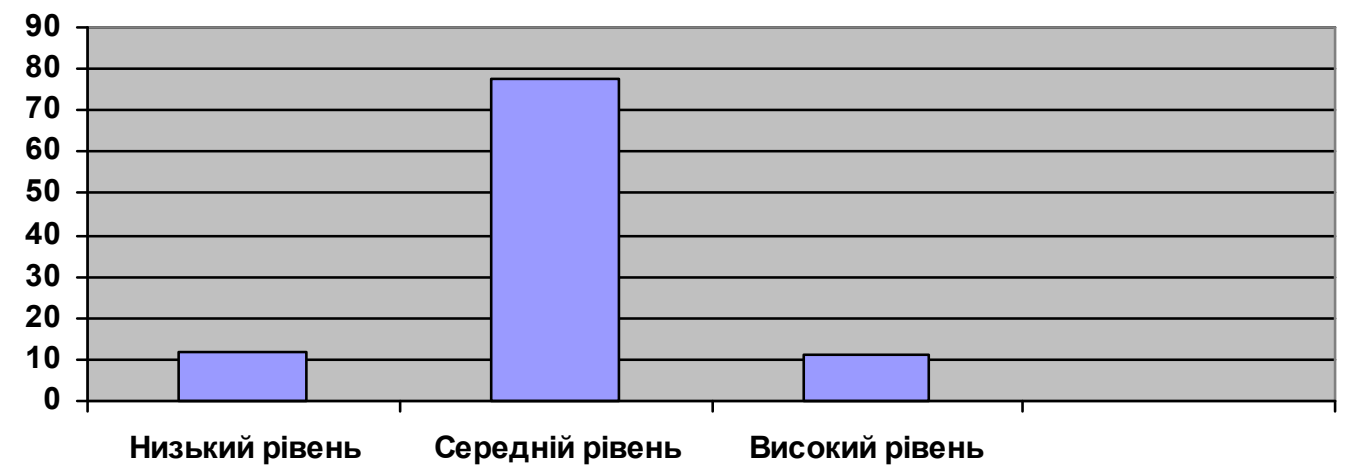

Рис 14. Рівні негативно-емоційного переживання студентів-психологів, які зоріснтовані на практику під керівництвом наставників у звичайному стані

3 опитування на визначення психологічних особливостей особистісного стану майбутніх психологів під час набуття ними професійної самоідентичності ми виокремили такі чинники: психологічні (самооцінка, стан загальної функціональної активності, пізнавальної активності, тривожності, нервово-емоційного стану), педагогічні (вплив наставників 3 психологічної практики, викладачів, членів професійної спільноти, одногрупників).

Рівні особистісно-професійних показників фахового становлення досліджуваних майбутніх психологів, які зорієнтовані на практику під керівництвом наставників показують недостатню їх особистісно-професійну спрямованість на свою майбутню професію за підтримки наставника. Майбутні психологи можуть бути не готовими сприйняти, зрозуміти настановлення наставника-спеціаліста потрібного для формування відповідної їхнім можливостям, здібностям установки на професію на фоні низького рівня 
сформованості їхньої ідентичності, що являє собою позицію, ставлення до мети або завдань майбутньої професії. Останні забезпечують відбіркове спрямування і готовність до діяльності та сприяють її здійсненню. Це є причиною неефективної співпраці студентів зі своїми наставниками у напрямку їхнього фахового зростання.

\section{Висновки}

Таким чином, за результатами теоретико-емпіричного вивчення проблеми формування професійної самоідентичності майбутнього психолога ми дійшли висновку стосовно того, що рівень розвитку професійної самоідентичності майбутнього психолога $€$ запорукою його ефективної самореалізації в майбутній професійній діяльності.

Перспективи наших подальших досліджень будуть зорієнтовані на визначення факторної ваги структурних компонентів професійної самоідентичності майбутнього психолога, що мають найбільшу інформативність та сутнісну значущість для становлення цього інтегративного особистісного утворення майбутнього психолога.

\section{Література}

1. Будасси, С.А. (1972). Самооценка личности. А.В. Петровский (Ред.), Практические занятия по психологии (с. 30-37). Москва.

2. Варбан, М.Ю. (1998). Рефлексія професійного становлення в юнацькому віці. Практична психологія та соиіальна робота, 6-7, 80-83.

3. Джемс, У. (1982). Личность. Ю.Б. Гиппенрейтер \& А.А. Пузырей (Ред.), Психология личности. Тексты (с. 61-70). Москва : Изд-во МГУ.

4. Овсянникова, В.В. (1981). Динамика «образа своей профессии» в зависимости от степени приобщения к ней. Вопросы психологии, 5, 133-137.

5. Панок, В., Титаренко, Т., \& Чепелєва, Н. (1999). Основи практичної психологї̈. Київ : Либідь.

6. Поваренков, Ю.В. (1991). Психология профессионального становления личности: (основы психологической конщепции профессионализации). Курск : Изд-во КГПИ.

7. Рогов, Е.И. (1999). Настольная книга практического психолога : учеб. пособие (В 2 кн.). Москва : Гуманит. изд. центр ВЛАДОС.

8. Стояно, О.О. (2004). Самоідентифікація студентства як процес самовизначення особистості в сучасному суспільстві. (Автореф. дис. канд. філос. наук). Одеса.

9. Шнейдер, Л.Б. (2004). Профессиональная идентичность: теория, эксперимент, тренинг. Москва : МСПИ. Воронеж : НПО «МОДЭК».

10. Эриксон, Э. (1996). Идентичность: юность и кризис. Москва : Прогресс.

11. Юм, Д. (2001). О тождестве личности. Санкт-Петербург : Азбука.

12. Adamek, R.L., \& Dager, E.Z. (1971). Social structure, identification and change in treatment-oriented institution. In Socialization (pp. 162-188). Chicago : Rand McMally.

13. Barbour, J., \& Lammers, J. (2015). Measuring professional identity: a review of the literature and a multilevel confirmatory factor analysis of professional identity constructs. Journal of Professions and Organization, 2(1), 38-60. doi: 10.1093/jpo/jou009

14. Ely, J.D. (1997). Community and the politics of identity: toward the genealogy of a nationstate concept. Stanford Humanities Review, 5(2), 70-95. Retrieved from https://web.stanford.edu/group/SHR/5-2/elly.html

15. Hansson, J. (2010). Libraries and identity. The role of institutional self-image and identity in the emergence of new types of libraries. Oxford: Chandos Publishing.

16. Neary, S. (2014). Professional identity: What I call myself defines who I am. Career Matters, 2(3), 14-15. Retrieved from http://hdl.handle.net/10545/324124

17. Pratt, M., Rockmann, K., \& Kaufmann, J. (2006). Constructing professional identity: The role of work and identity learning cycles in the customization of identity among medical 
residents. Academy of Management Journal, 49(2), 235-262. doi: 10.5465/AMJ.2006.20786060

18. Tenopir, C., King, D.W., Spencer, J., \& Wu, L. (2009). Variations in article seeking and reading patterns of academics: What makes a difference? Library \& Information Science Research, 31(3), 139-148. doi: 10.1016/i.lisr.2009.02.002

19. Waterman, A.S. (1982). Identity development from adolescence to adulthood: Anextension of theory and a review. Developmental Psychology, 3(18), 341-358. doi: 10.1037/0012$\underline{1649.18 .3 .341}$

\section{References}

1. Budassi, S.A. (1972). Samoocenka lichnosti [Self-esteem of personality]. In A.V. Petrovskij (Ed.), Prakticheskie zanjatija po psihologii - Practical studies in psychology (pp. 30-37). Moscow [in Russian].

2. Varban, M.Iu. (1998). Refleksiia profesiinoho stanovlennia v yunatskomu vitsi [Reflection of professional formation at a young age]. Praktychna psykholohiia ta sotsialna robota Practical Psychology and Social Work, 6-7, 80-83 [in Ukrainian].

3. Dzhems, U. (1982). Lichnost [Personality]. In Iu.B. Gippenreiter \& A.A. Puzyrei (Eds.), Psikhologiia lichnosti. Teksty - Psychology of personality. Texts (pp. 61-70). Moscow : Izdvo MGU [in Russian].

4. Ovsjannikova, V.V. (1981). Dinamika «obraza svoej professii» v zavisimosti ot stepeni priobshhenija $\mathrm{k}$ nej [The dynamics of the «image of your profession» depending on the degree of familiarization with it]. Voprosy psikhologii - Questions of Psychology, 5, 133-137 [in Russian].

5. Panok, V., Tytarenko, T., \& Chepelieva, N. (1999). Osnovy praktychnoi psykholohii [Fundamentals of practical psychology]. Kyiv : Lybid [in Ukrainian].

6. Povarenkov, Ju.V. (1991). Psihologija professional'nogo stanovlenija lichnosti: (osnovy psihologicheskoj koncepcii professionalizacii) [Psychology of professional formation personality: (the basis of the psychological concept professionalization)]. Kursk : Izd-vo KGPI [in Russian].

7. Rogov, E.I. (1999). Nastol'naja kniga prakticheskogo psihologa [Handbook of the Practical Psychologist] (Vols. 1-2). Moscow : Gumanit. izd. centr VLADOS [in Russian].

8. Stoiano, O.O. (2004). Samoidentyfikatsiia studentstva yak protses samovyznachennia osobystosti $\mathrm{v}$ suchasnomu suspilstvi [Self-identification of students as a process of selfdetermination the individual in the modern society]. Extended abstract of Candidate's thesis. Odesa [in Ukrainian].

9. Shnejder, L.B. (2004). Professional'naja identichnost': teorija, eksperiment, trening [Professional identity: theory, experiment, training]. Moscow : MSPI. Voronezh : NPO «MODJeK» [in Russian].

10. Jerikson, Je. (1996). Identichnost': junost' $i$ krizis [Identity: Youth and Crisis]. Moscow : Progress [in Russian].

11. Jum, D. (2001). O tozhdestve lichnosti [About identity]. Sankt-Peterburg : Azbuka [in Russian].

12. Adamek, R.L., \& Dager, E.Z. (1971). Social structure, identification and change in treatment-oriented institution. In Socialization (pp. 162-188). Chicago : Rand McMally.

13. Barbour, J., \& Lammers, J. (2015). Measuring professional identity: a review of the literature and a multilevel confirmatory factor analysis of professional identity constructs. Journal of Professions and Organization, 2(1), 38-60. doi: 10.1093/jpo/jou009

14. Ely, J.D. (1997). Community and the politics of identity: toward the genealogy of a nationstate concept. Stanford Humanities Review, 5(2), 70-95. Retrieved from https://web.stanford.edu/group/SHR/5-2/elly.html

15. Hansson, J. (2010). Libraries and identity. The role of institutional self-image and identity in the emergence of new types of libraries. Oxford : Chandos Publishing. 
16. Neary, S. (2014). Professional identity: What I call myself defines who I am. Career Matters, 2(3), 14-15. Retrieved from http://hdl.handle.net/10545/324124.

17. Pratt, M., Rockmann, K., \& Kaufmann, J. (2006). Constructing professional identity: The role of work and identity learning cycles in the customization of identity among medical residents. Academy of Management Journal, 49(2), 235-262. doi: $\underline{\text { 10.5465/AMJ.2006.20786060 }}$

18. Tenopir, C., King, D.W., Spencer, J., \& Wu, L. (2009). Variations in article seeking and reading patterns of academics: What makes a difference? Library \& Information Science Research, 31(3), 139-148. doi: 10.1016/j.lisr.2009.02.002

19. Waterman, A.S. (1982). Identity development from adolescence to adulthood: Anextension of theory and a review. Developmental Psychology, 3(18), 341-358. doi: 10.1037/0012$\underline{1649.18 .3 .341}$

\title{
PSYCHOLOGICAL AND PEDAGOGICAL FEATURES OF ESTABLISHING THE PROFESSIONAL SELF-IDENTITY OF A FUTURE PSYCHOLOGIST Inna Boichenko
} Scientific Researcher at the Department of Youth Problems Research

State Institute of Family and Youth Policy

17 a, Esplanade Str., Kyiv, Ukraine, 01023

i_boych@ukr.net, http://orcid.org/0000-0002-2607-5612

\begin{abstract}
The article is dedicated to the theoretical and empirical studying of an issue of future psychologist professional identity formation. The article focuses on the necessity of taking into account the features of its structural components in the professional training of studentspsychologists. The concepts «professional identity», «professional identification», «professional self-identity» and «professional self-identification» are theoretically grounded in the article. Professional identity is considered as one of the important newly formed element in the personality of adolescents. It is noted the relationship of the formation of professional identity with the process of professional self-determination. The dependence of the effective fulfillment of a psychologist in the future from the formation of his/her professional identity is established. It is proved that the processes of cognitive and personal development of psychologists in the aggregate provide the basis for the formation of their professional identity in the process of mastering professional competencies. The professional identity is considered as a dynamic structure that evolves and changes throughout a person's life. Professional identity is determined by such components as existential, role and personal self-categorization, which involves the functional and the existential relationship of a person and profession. The factors influencing the formation of professional identity of future psychologists are identified. The models of professional identity of future psychologists are analyzed. The article is focused on the fact that the personality of the future specialist is one of the most important components of a successful model of formation professional self-identity. The level of awareness of students-psychologists to determine their profession in the process of becoming their professional identity is determined. Indicators of students' ability to self-identity are defined. The factors that determine the effectiveness of students' professional identity are distinguished. The influence of psychological and pedagogical factors on the formation of self-identity is analyzed.
\end{abstract}

Keywords: professional identity, professional self-identity, professional identification, professional self-identification, structural components, factors, model, future psychologist.

Подано 27.01.2020

Рекомендовано до друку 08.02.2020 